DE DE GRUYTER OPEN
Research Article

(C) 2017 Humphrey Nwefuru Nwobashi and Anthony Itumo. This is an open access article licensed under the Creative Commons Attribution-NonCommercial-NoDerivs License (http://creativecommons.org/licenses/by-nc-nd/3.0/).

\title{
Democracy and Contributions of Town Union to Educational Development in Ebonyi State: A Focus on Some Selected Rural Communities
}

\author{
Nwobashi, Humphrey Nwefuru*, PhD \\ Itumo, Anthony, PhD \\ Department of Political Science, Faculty of Social Sciences and Humanities \\ Ebonyi State University, P.M.B 053, Abakaliki \\ ${ }^{*}$ Corresponding Author
}

Doi: 10.1515/mjss-2017-0005

\begin{abstract}
This study interrogates the nexus between democratic governance and the contributions of town unions to provision basic education in rural communities in Ebonyi State. The study was carried out in twelve selected rural communities chosen across the three senatorial zones of the state. The study was provoked by need to empirically test the contentious debate among development scholars over the correlation between democracy and development. The data for the study were gathered through the use of questionnaire, Focus Group Discussion (FGD), observation and documentary methods. The study adopted community action theory as its framework of analysis. The data were analyzed using simple percent, contingency tables, and histogram while chi square was used for the test of hypotheses. The findings revealed that democratic governance has increased contributions of town unions in the provision of basic education in rural communities in Ebonyi State. The study equally revealed that lack of enlightenment, illiteracy, and poverty among the rural dwellers poses challenge to the contributions of town unions in the provision of basic education. The study recommended that government should provide periodic subventions to town unions to enable them mobilize adequate funds for the provision of basic educational projects. Besides, leadership trainings should be organized on regular basis to educate and enlighten town union executives on the best global practices on rural development.
\end{abstract}

Keywords: Basic Education, Democracy, Development, Rural Communities, Town Union

\section{Introduction}

This study interrogates the capacity of democratic governance to spur the contributions of town unions to the provision of basic education in selected rural communities in Ebonyi State of Nigeria. The study is provoked by the need to empirically test the efficacy of the controversial debate currently ranging among development scholars over the correlation between democracy and development while some development scholars portend a positive correlation and the other group of scholar portends a negative correlation.

In this regard, two core arguments dominate the literature on correlation between democracy and development. The first strand of argument posits that economic development is a driver for the realization of democracy. For this school, economic development is sine qua non for the realization of democracy. This means that economic development is prerequisite for achieving democracy in any society as such any society that wants to experience democratic development must first pursue development.

This line of thought flourished greatly especially in 195os and 1960s among development scholars. The core argument in the 1950s and 1960s was that "the more well-to-do a nation, the 
greater the chances that it will sustain democracy" (Lerner, 1958: 63; Lipset, 1959: 31). A number of quantitative analysis in Political Science in these periods found economic development and a higher GNP per capita to be intricately linked to political democratization (Cutright, 1963; Neeler, 1968; Neubaur, 1967; Flanigan \& Fogelman, 1971; Flora, 1973; Marquette, 1974; Coulter, 1975; Bollen, 1979). In fact, a comprehensive effort to locate the correlates of democracy for over 100 countries, using political indicators for 1960 and 1965, which made Bollen and Jackson to report that "the level of economic development has a pronounced effect on political democracy, even when other non-economic factors are considered" (Bollen \& Jackman, 1985: 38-39).

The second argument posits that democracy produces environment that leads to economic development because of the basic principles of democracy which ensure accountability, checks and balances provisions, the dignity of the individual persons, freedom of expression and association, popular control and political equity, political participation, supremacy of the will of the people, open communications between the leaders and the led etc (Fukuyama, 1992; Cheema and Maguire, n.d; Doyle, 1983; Huntington, 1993; Feng, 2003; and Okolie, 2015).

Supporting this argument, Ake (1996) affirms that there is a strong positive relationship between democracy and development. For him democracy is a process while development is an outcome. This means that democracy is a process that brings about development and as such countries that want to experience development must first embrace democracy. It is just like the biblical dictum; "seek first the Kingdom of God and every other thing shall be added unto it." This argument is corroborated by Nnoli (2011), when he avers that democracy offers a viable path to a better political life that has the embededness of forces that propel socio-economic advancement in a polity. He further buttressed that when the citizens and elites of a country toe the right democratic path, democracy promotes the forces of positive change and discourages constraints against development.

The core argument is that the democratic governance limits the abuse of power by leaders because of the prevalence of elections and other processes due to rewards and punishments inherent in democracy. As such democracy brings about development because it guarantees predictable, peaceful and reliable procedure for transition of political power. The above qualities of democracy pave ways for robust economic activities through popular participation of citizen. Relying on the conventional wisdom that flows from the philosophical foundation of the second school thought, coupled with the weightier and more rewarding empirically evidence from the field survey, this study anchors its argument on the proposition of the second school.

Based on the above position, there have been expectations that democratic governance that was ushered in 1999 would invigorate and spur more participation of town unions in rural development drive in Nigeria. A close observation of rural development trends in rural communities in Ebonyi State raises serious academic puzzles on the reality of the acclaimed positive correlation between the two afore-stated variables. Against this backdrop, this study interrogates the efficacy of democratic governance to spur the contributions of town unions to the development of rural communities in Ebonyi State with specification attention on the provisions of basic education from 1999 to 2015.

\section{Statement of the Problem}

There is contentious debate among development scholars over the correlation between democracy and development. The first strand of debate posits that economic development is a driver for the realization of democracy. For this school, economic development is sine qua non for the realization of democracy. This means development first and then, comes democracy. Accordingly, a country that wants democracy must first embrace development before pursuing democracy. This line of thought flourished widely and greatly dominated researches especially in 1950s and 1960s (see, Cutright, 1963; Neeler, 1968; Neubaur, 1967; Flanigan \& Fogelman, 1971; Flora, 1973; Marquette, 1974; Coulter, 1975; Bollen, 1979). The assertion was that "the more well-to-do a nation, the greater the chances that it will sustain democracy" (Lerner, 1958: 63; Lipset, 1960: 31; Bollen \& Jackman, 1985: 38-39).

The second strand of debate posits that democracy is the vehicle that takes a country to 
development (Nnoli, 2011; Ake (1996). The assertion is that democracy produces environment that leads to economic development (Fukuyama, 1992; Cheema and Maguire, n.d; Doyle, 1983; Huntington, 1993; Feng, 2003; and Okolie, 2015). For this school it is democracy first before development.

In line with this stream of thought the popular thesis that dominated the literature during military era in Nigeria was that rural communities would witness accelerated contributions of town unions in the provision of social amenities if the country embraced democratic governance. (Cheema \& Maguire, n.d; Doyle, 1983; Huntington, 1993; Feng, 2003; Menocal, 2007). Following the above assertion, there have been high expectations that the enthronement of democratic governance in 1999 would further invigorate and spur the contributions of town unions in the building and maintenance of primary and secondary schools (Sen, 1999b; Pippa, 1999; Kiyaga-Nsubuga, 2015).

Despite the richness of this debate and the need to empirically test the efficacies of their argument in Ebonyi State, after eighteen years of uninterrupted democratic governance, scholars have paid fleeting attention to this important academic concern in Ebonyi State. For instance, most of the studies reviewed were carried out in geographical settings other than Ebonyi State (Adebayo, 1995; Onyeozu, 2010; Ugwu, 2013 \& Bashir, 2015) which is the focus of this study. Worse still, these studies focused on general issues of development and failed to interrogate the town unions as intervening variables which is the core mandate of this study. The implication of the existing knowledge gaps is that the findings and conclusions drawn from these studies cannot be extrapolated for the explanation of the same problem in Ebonyi State, hence, the need for this study. To fill this void, the researchers raised the following research questions to guide the study:

1. Has democratic governance increased the contributions of town unions in the provision of basic education in rural communities in Ebonyi State?

2. What could be done to enhance the capacity of democracy to spur the contributions of town unions to the provision of basic education in rural communities in Ebonyi State?

\section{Review of Related Literature}

\subsection{Democracy and Rural Development}

There is a need to review related literature that attempts to situate the relationships between local governance and rural development so as to knit them together as the building blocks in this study. It is believed that democracy provides the conditions that can address the relevant development issues to systems of rural governance. It enables patterned function for the non-state actors such as civil society groups - business and professional bodies, faith-based organizations, philanthropy organizations and community based organization to corroborate with public officials in order to achieve sustained relationship and synergy. This is why Sisk (2001) opines that more open and democratic countries recent are attributed to their being responsive to local governance. Dewey (1927) insists that political relations of public and government leaders do not by any means exhaust democracy. In his own view, democracy is appropriate to all modes of human association, the family, the schools, industry, religion or any other form of extensive and enduring mutually affecting interaction among people. Democracy, justice, liberty and equity are working if a great number of citizens are aware of programmes and processes and that they can access public decision and act collectively to ensure the realization of their rights. However, if all of these objectives are not properly served, they will be deformed which limits their ability to get involved and contribute their quota (Westergaard \& Alam, 1995; Parry 1997). "Information asymmetries are...a key problem: either they must be righted, or an otherwise desirable course of action will not produce the assumed results" (Tendler and Serrano, 1999: 51).

Aligning himself to the above proposition, Lipset (1959) interrogated the relationship between a sound economic development and sustainable democracy and establishes that they both correlate. Since then, the debate in the linkages between democratic governance and development has raged on. The issue was approached in line with economic growth model only instead of a more comprehensive human development index approach. According to Santiso (1997), this contestation centred on the following factors: (i) whether democracy is a condition for stimulating 
wealth and growth; (ii) whether improved income and prosperity foster democracy; (iii) whether there is a synergic between democracy and economic growth.

Scholars have differed as to the questions of whether democracy stimulates economic growth or vice versa. Przeworski and Limonel (1993) concluded that they are unaware as to whether democracy promotes or constrains economic growth. Later, Przeworski (2000) in his own view admits that democracies are more likely to flourish in prosperous nations. Kaplan (1997) concurred that there certain preconditions that should be available in the country for democracy to firmly be on the ground including but not limited to some degree of job availability, economic prosperity and secured environment. Kaplan supports this opinion by maintaining that "economic prosperity increases the opportunities that make democracy more sustainable.

Indeed, some studies have contrasted between democracy and economic prosperity. Towasine (1998: 53) for instance states that nothing is in place to demonstrate that there is improvement in the living standard of the people that can create for themselves conducive environment for the sustenance of democracy. Others find a strongly positive one (Sen, 1998; Przeworski, 2000). The correlation depends on factors such as history, type of democracy, resources, social and societal structure etc. Arguing this correlation further, Sen, in Cheema and Maguire (n.d: 42) wrote that:

No substantial famine has ever occurred in a democratic country because a government which has to deal with opposition parties, to answer unfriendly questions in parliament to face condemnation from public media and to go to polls on regular basis, simply cannot afford not to take prompt action to avert a threatening famine.

A study by the United Nation (2000) indicates that democracy and growth are inseparable. The research reveals that except the two that are exceptional, the richest countries in the world that have a per capita income of $\$ 20,000$ or more are the most democratic. The OECD (2001) alludes to this fact when it characterized governance as: participatory, citizen-centred, accessible, responsible, credible, functional, fairness, and inclusive which is governed by the letter and the spirit of the law and permits some views proffer by the majorities and some voices of the weakest group in the society in matters that affect the citizens.

Even though, some scholars have eulogized democracy as observed in the preceding reviewed works, Maiangwa (2013) was astonished at the performance of democracy in Africa that he aptly queried whether democracy is crawling or falling in Africa? Diamond (1996) commented that Africa lags behind economically because it lags behind in democratic governance. He argued that the bitter challenge is that African countries lack governance agenda and its democracy is trial and error model which Sahl (1989) insists is a shaky democracy. Maiangwa was tempted again to ask why this is common in Africa. He reiterated that may be the environment of Africa does not agree with the western model of democracy which has made it difficult to practice. The black feature of democracy in Africa provoked people to criticize the western liberal type of democracy and for them to search for alternatives that can provide solution to their basic needs of life that have remained in want as they practice democracy. While reacting to the quest for alternative brand of democracy for Africa, Dahl (1989) cautions that there is no alternative to democracy.

In Nigeria's context, Omenka and Akaan (2013) observed with sadness that no meaningful development has been permissible due to what Diamond (1996) describes as the prevalence of "low quality democracy in Nigeria. Ake's characterization of Nigerian - democracy is very informing. He asserted as follows:

We are intoxicated with politics. The premium on political power is so high that we are prone to take the most extreme measures in order to win and maintain political power. Our energy tends to be channeled into the struggle for power to the detriment of economically productive effort and we habitually seek political solutions to virtually every problem such as the political economy of social life in Nigeria (Ake, 1998:49).

As a result therefore, the country remains incapable of having a stable democracy with permanent political structures that engender socio-economic and political environment. Having extrapolated the relationships between democracy, development and governance general, let us narrow our review to local governance and rural development. 


\subsection{Town Unions and Rural Development}

Modern concept of Town union as a tool for advancing rural development emerged during colonial era especially as result migration people to the colonial cities. The colonial masters had no welfare plan for the people migrating from rural to urban areas. The urban areas became difficult and strange for the hitherto rural people.

Eme et al. (2012) asserts that the idea of town union started as means of taking care of the welfare of their members far from home. Against this spirit many Africans that moved into the urban areas involved themselves in social relations to serve as the traditional society. They also attached themselves to their homes which made them believed they will come back to their ancestral home some day. Furthermore, they felt that the diverse infrastructural facilities and services these unions enjoyed in the urban centres; they would want to have and enjoy in their home Towns. This nostalgic feeling may be regarded as the magic wand that some communities have used in placing town unions as a useful instrument for achieving self-reliance and development rural areas in Nigeria (Ugwu, 2013).

The increasing underdevelopment crises have caused people to asked question on the actual function of Nigerian state and their related institutions in socioeconomic development. This is due largely to persistence of such underdevelopment crises which are seen as proof of poor performance of Nigerian state. Beginning from mid 1980s, academics and policy commentators have demonstrated profaned interest in the role of Town unions play in the social and economic development and local governance of communities in the third world countries (Ugwu, 2013). There have been multiplier consciousnesses of the people to see the need to place a more robust organization and administrative bodies which can provide and foster stable self-reliant development in their local communities.

Third world scholars and government actors are now realizing that town unions and indigenous institutions have proved to be more successful in engendering development in rural communities comparable what the state has done in socio-economic development. Richards, (1985) and Ake (1987) cited in Nwosu (1999) contended that in Nigeria, despite of the effort made in recent years to decentralize local governance, it remains insufficient to adequately address the development at the grass root reverse.

Nwankwo (2014) opined that participation by the community increases the probability that decisions will effectively be implemented. He pointed out that social scientists have come to understand that when target groups are involved in the process of development, they are satisfied with such development, again such group will feel a sense of belonging and their initiatives and potentialities are effectively utilized.

In some African communities such as Nigeria, particularly, the Igbos being one of the major tribes in country, Town unions through their Age Grade Associations have performed various tasks depending on the felt need of the people and what was assigned to them by the Town union (Ugwu, 2013). Today in many Igbo societies like Ohafia, Abriba etc, these age grades have accomplished important tasks and are still accomplishing various strides in community development. According to Eme et al. (2012) in Okigwe, Ohafia, the Okpatemba being their age grade has constructed a state of the art two storey building town unions have achieve great development activities and are still doing more in their various communities.

The emergence of town unions and their involvement in rural community development have remained as old as Igbo nation. Honey et al. (1998) citing Chinua Achebe highlighted the programmes of Umuofia progressive union in one of Achebe's novel, which feature prominently the help the union rendered to one of the promising son of Umuofia, Obi Okonkwo. Eje (1988) cited in Nwosu (1990) has reiterated the significant impact in reconstruction of facilities and infrastructures at the end of the civil war. He asserted that health facilities, rural roads and bridges, various market and other projects were reconstructed and new constructed by various town union. Besides, primary and secondary schools' building and the equipment of new ones were also initiated by town unions. Therefore, town unions have continue to serve as veritable instrument for local governance.

Bonsu (1983) affirms that town development union's participation in rural development has been age long development approach in Africa. He maintains that this has led to development in 
many towns and villages. The idea is that since such development initiative comes from the people, it directly reflects their needs and aspirations, as such to make rural development work. Nwobi (2007) posits that the people of the localities should play the role of managers and entrepreneurs of development. This is because having the ingredients of development such as land, capital and labour is not enough to enhance development until a man tries to act on the biophysical environment to eke out something out of it.

Distilled from the analysis, it points to the fact that in all cases, each community in all the states of the South East has a town development union which may be called Community Development Association or Community Progressive Association, normally led by a president and works in concert with other elected members of the executive. Town development unions championed development projects, guarantee internal security and liaise with governmental authorities to attract social amenities to their communities.

\subsection{Town Unions and Provision of Basic Education}

This stream of studies explored the contributions of town unions to the provision of development projects especially in the educational sector. Specifically, most of these studies focused on the examination of how towns union contribute to the funding of school building projects, class room desks, furnishing of teachers' offices among others.

Contributing to this strand of literature, Waldman (2012) took a critical study of democratic governance and its effects on the educational development policy in Unites States of America. He synthesized the theories of Madison and Rousseau to demonstrate a broad theoretical understanding of how democratic institutions govern as well as how educational inequalities are resolved in democratic system. Moreso, he analysed Dewey's theoretical background for comparing American education with the democratic governance theories of Madison and Rousseau coupled with Bertalanffy general system theory to demonstrate how the new governance theory of centripetalism and Dewey's philosophy of education, can be synthesized to become a theoretical foundation for an education development policy.

The study concludes that learning objective will construct broad spectrum on how developing nations may model a blend of the best ideas of Madison's and Rousseau's democratic governance that promotes sustainable educational development opportunities. The problem with this study is that it is too general and lacks focus as it examined booth rural and urban communities in United States rather focusing specifically on how democracy could spur town unions to fund educational development in rural communities which is the trust of this study. Again, the study aims at establishing how different new democratic governance theories could be synthesized to produce a theoretical foundation for an educational develop policy in United State rather than understanding how democracy could enhance town unions funding of educational development.

In another study, Oladepo (1996) examined how town unions contribute to funding of basic education in rural areas in Oyo State, Nigeria. The researcher applied survey method and distributed questionnaires to 55 primary schools in Kajola Local Government Area of the state. The data were analyzed with the instrumentality of chi square. After the analysis the researcher reported that out of the 55 primary schools in Kajola Local Government Area of Oyo State, only 7 are Local Government-owned while the larger proportion (48) schools were established by the CBOs. It must however be noted that most of the primary schools are located in the rural settlements of the LGA. The problem with this study is that even though it focused how town unions contribute to funding basic education in rural communities, it still lacks in focus as it did not examine how democratic governance could facilitate the contrition of town unions in the funding educational projects. Again, the study fail far short of explaining the problem understudy as it was carried out in far away Oyo State in the southwestern Nigeria as such cannot be extrapolated to explain similar situation in Ebonyi state. It is imperative to note that since Ebonyi state is educationally disadvantaged state the dynamic factors that propel its internal development especially in education are likely different.

In a related study, Ugwu (2013) investigated town unions' contributions to community development in Nsukka L.G.A. in Enugu state of Nigeria. The study utilized survey method and applied self report technique of data collection which deals mostly with sourcing information from 
the primary sources and analytical induction sourcing information from secondary sources. Data collected were analyzed using quantitative methods. The result showed that town unions established and refurbished 40 primary schools at the total cost of N9,903,000.00 within the period covered by the study, while at the same time, 19 secondary schools were constructed across the communities at the cost of N15,800,000. The study having established the contributions of town unions to funding of basic education in the local government concludes that it is not easy for government to singlehandedly and adequately fund education sector effectively. To this end, Town Unions in Nsukka Local Government Area contributed in construction and renovating, existing structure in primary and post-primary institutions. They also helped in equipping the schools by providing some facilities like chair and tables for both teachers and pupils. In some communities, Town Unions contributed to repairing of leaking roofs of the schools and constructing of libraries which will inculcate the reading habit in the pupils. In this way Town Unions have contributed in improving the standard of living of the people. The problem of the above study when compared with this present study is that it studied Nsukka Local Government Area which is located in urban area instead of rural communities which is the focus of this study. Again, the study utilized self report technique of data collection rather than questionnaire and focus group discussion as such, the outcomes of the two studies are not likely to produce identical results.

In related study, Bashir (2015) evaluated the contribution of Community Based Organisations (CBOs) to the development of communities in Nigeria with a focus on Offa Local Government Area of Kwara State. The objectives of the study among others were to find out the contributions of $\mathrm{CBOs}$ to rural development and to identify the immediate and remote causes of the challenges militating against CBOs participation in rural development in the area. The research problem is therefore to unveil the poor performance of these CBO's in the area understudy. The study mostly used secondary data, and supplemented by primary data. Simple percentages were used to analyze data collected.

The study reveals that CBOs provide socio-economic facilities for the common benefit of the community. It affirms that this type of organization has been in existence in Offa Local Government Area even before the creation of the Local Government in 1991. It discovers that in the past, CBOs have contributed immensely to the socio-economic development of Offa LGA by the provision of schools, community health centres, feeder roads, market stalls, motor parks etc but of recent it notices a decline in the performance of these organizations. The study equally reveals among others that the poor performance of the CBOs is due to the poor working relationship between them and the local government particularly financial assistance. It recommends that Offa Local Government should assist these CBOs in order for them to perform and achieve their objectives.

Although, this study is vital for our understanding of CBOs' contributions to the development of rural communities in rural communities in Kwara state in Nigeria, it fail far short of explaining how democratic governance stimulate town unions' contributions to funding of educational projects. As such there is need for specific study for the purpose of finding out the contributions of town unions to funding of educational projects in rural communities in Ebonyi state to avoid over generalization in extrapolating the findings from this study to the explanations of similar case in Ebonyi state.

\section{Theoretical Framework}

The researcher adopts "community action theoretical model" as its framework of analysis. The community action theoretical model was propounded by Freire in 1973. The theory emphasizes the need for communities to collectively strengthen their capacity to develop through educational (Kulig, 2000). Implicit in this theory is that residents in poor communities can team together to attain socio economic development (Boreham, 2004) through education. This means that community action model involves participatory action approaches and is asset based. That is to say that it builds on the strengths of a community to create changes from within (Racher, 2007). Its intention is to change by building community capacity, working in collaboration with communities and providing a framework for residents to acquire skills and resources necessary for assessing their socio economic conditions (Lavery, 2005). When they have done this, they can plan, implement and evaluate actions designed to improve those conditions. 
This means that the model is designed to increase the capacity of communities and organisations in addressing their socio-economic determinants that will positively influence development in their rural communities (Anderson \& McFarlane, 2004). The relevance of this theory to this study is hinged on the fact that it can help us to explain the contributions of town development unions in the funding of basic education and health facilities in rural communities in Ebonyi state. From the above theoretical proposition it is axiomatic to draw the following hypothesis: Democratic governance has increased the contributions of town unions in the provision of basic education in rural communities in Ebonyi State.

\section{Methodology}

The research design adopted for this study is cross-sectional survey design. This study was carried out in twelve selected communities from the six Local Government Areas chosen from the three senatorial zones. These communities comprised Amagu and Enyibichiri communities in Ikwo LGA and Umuezeokoha and Eka communities in Ezza North Local Government Area located in Ebonyi Central Senatorial District. Others are: Igbeagu and Ezza-Inyimagu communalities in Izzi LGA, Umuogodo Akpu and Umuezeaka communities in Ohaukwu LGA in Ebonyi North Senatorial District while in Ebonyi South Senatorial District, Ugwulangwu and Okposi Ukwu communities in Ohaozara LGA and Owutu Edda and Nguzu Edda communities in Afikpo South LGA.

A population of four hundred and twenty two thousand four hundred and forty two $(422,442)$ participated in the study. The participants were selected from religious leaders, women leaders, public office holders/civil servants, youths/students, community/town union leaders past and present from the selected communities. It is imperative to note that the study employed multistage sampling procedure.

The data for study were sourced through the use of questionnaire instruments, observation, and focus group discussions, while the other set of data were obtained from the internet, text books, journals, newspapers, and magazines. The statistics instrument used for the analysis and presentation of data were simple percentage frequency tables and histogram while chi-square was used for the test of hypothesis

\section{Data Presentation and Analysis}

This section deals with the analysis and presentation of the sampled respondents' views on the major theme of the subject under study. The data were generated in line with the research questions and results presented in figures 1-5

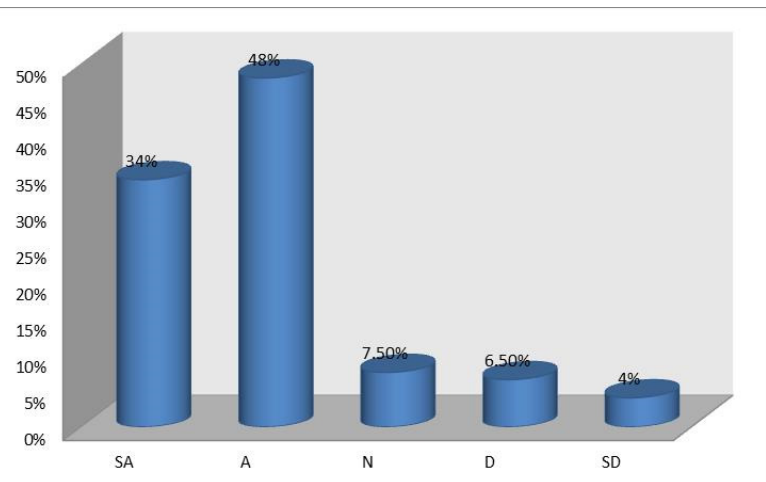

Figure 1: Histogram on how democratic governance has enabled town unions to seek the views of community members in the choice of primary and secondary schools

Source: Humphrey Nwobashi and Itumo Anthony's Field survey, 2016 
The data in figure 1: shows the analysis of the sampled respondents on questionnaire item one. The result indicated the followings: strongly agreed (493 representing 34\%), agreed (697 accounting for $48 \%$ ), neutral (109 representing 7.5\%), disagreed (94 accounting for 6.5\%) and strongly disagreed (58 representing 4\%). From these responses, it was observed that larger proportion of the sampled respondents admitted that democratic governance has enabled town unions to seek the views of community members on their choice of primary and secondary schools projects in their communities.

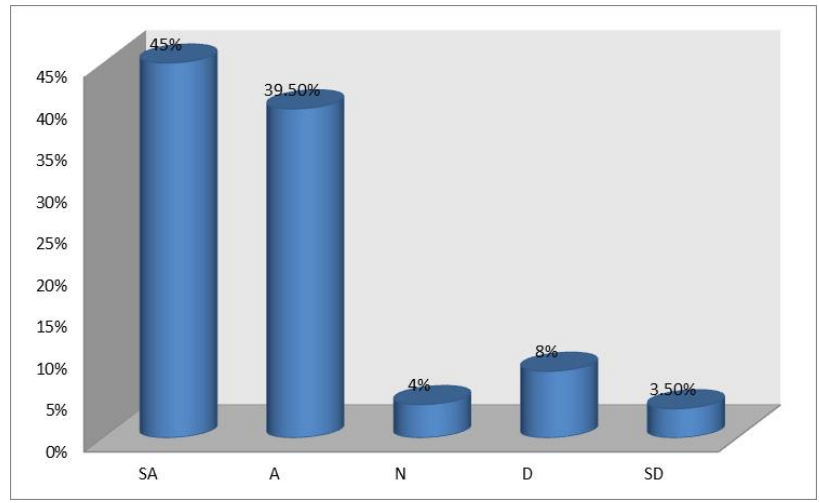

Figure 2: Histogram on how democratic governance has promoted increased consultation between town unions and community members in mobilization of fund for the provision of instructional materials in primary and secondary schools

Source: Humphrey Nwobashi and Itumo Anthony's Field survey, 2016

Figure 2 shows the distribution of the sampled respondents on questionnaire item 2. The responses indicated the followings: 653 representing $45 \%$ strongly agreed, 573 accounting for $39.5 \%$ agreed, 58 of the respondents representing $4 \%$ neutral, 116 accounting for $8 \%$ disagreed and strongly 51 representing $3.5 \%$ disagreed. The above analysis indicated that majority of the sampled respondents accepted that democratic governance has promoted increase consultation between town unions and community members in mobilization of funds for the provision of instructional materials in primary and secondary schools in their communities.

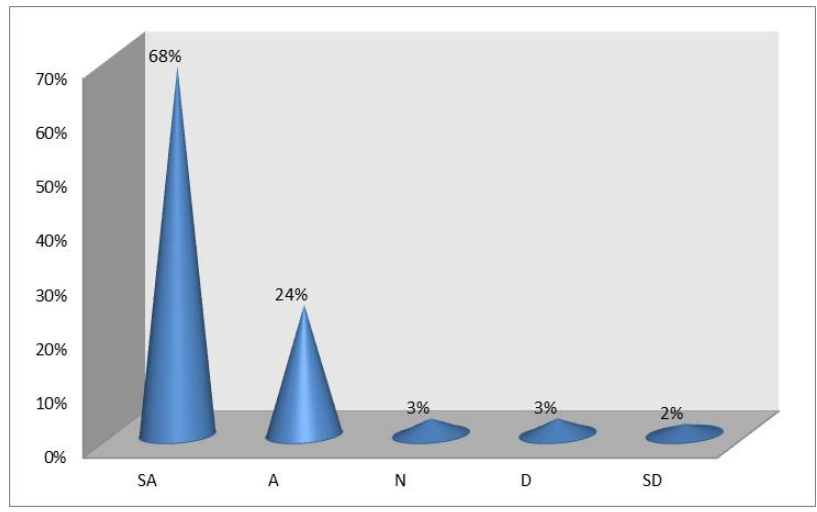

Figure 3: Histogram on how democratic governance has facilitated the involvement of community members by town unions in the advocacy for increased primary and secondary schools enrolment Source: Humphrey Nwobashi and Itumo Anthony's Field Survey, 2016 
The data in figure 3 shows the distribution of the respondents on questionnaire item 3 . The responses indicated the following: strongly agreed $68 \%$ accounting for 986 of the sampled respondents, agreed $24 \%$ representing 348 of the sampled respondents, neutral $3 \%$ accounting for 44 of the sampled respondents, disagreed 3\% representing 44 of the sampled respondents and disagreed $2 \%$ representing 29 of the sampled respondents. From these responses, it was observed that greatest percentage of the sampled respondents affirmed that democratic governance has facilitated the involvement of community members by town unions in the advocacy for increased primary and secondary schools enrolment in their communities.

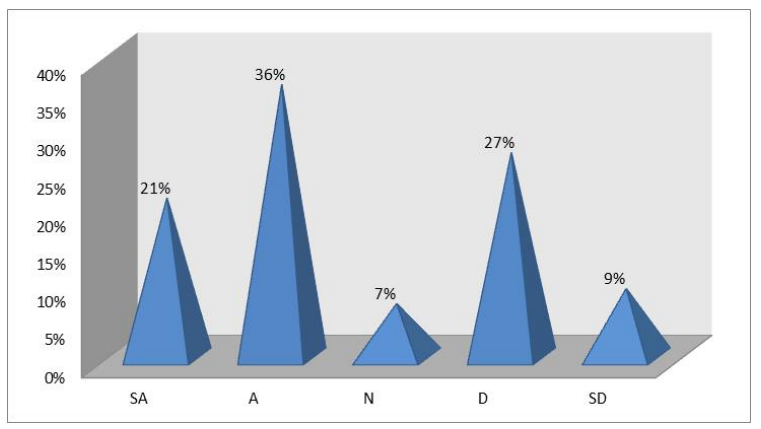

Figure 4: Histogram on how democratic governance has aided increase collaboration between community members and town unions in the provision of recreational activities and sponsorship of sporting events in primary and secondary schools

Source: Humphrey Nwobashi and Itumo Anthony's Field survey, 2016

The data in figure 4 indicates the distribution of the sampled respondents on questionnaire item 4. The obtained responses were as follows: strongly agreed $21 \%$ representing 305 of the sampled respondents, agreed $36 \%$ accounting for 522 of the sampled respondents, neutral $7 \%$ representing 102 of the sampled respondents, disagreed $27 \%$ accounting for 392 of the sampled respondents and strongly disagreed $9 \%$ representing 130 of the sampled respondents. Based on these responses, it was observed that majority of the respondents shared the opinion that democratic governance has aided increased collaboration between community members and town unions in the provision of recreational activities and sponsorship of sporting events in primary and secondary schools in their communities.

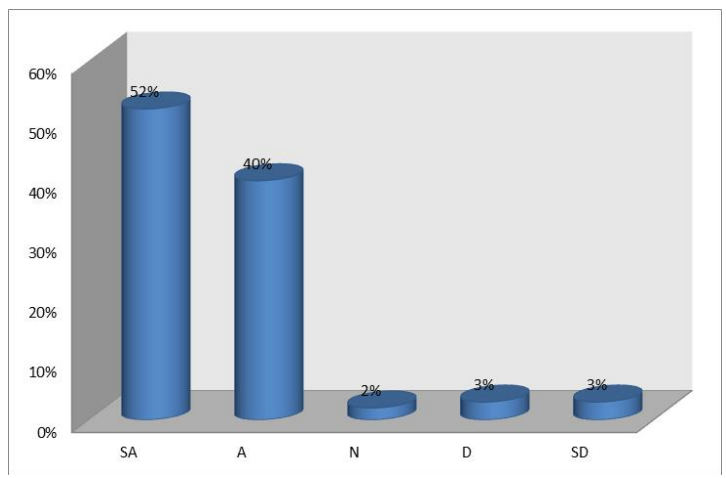

Figure 5: Histogram on how town unions enlightened the community members on the importance of education in the liberation of the people from ignorance and servitude.

Source: Humphrey Nwobashi and Itumo Anthony's Field survey, 2016 
The result in figure 5 shows that more than half (52\%) representing 754 of the sampled respondents indicated strongly agreed, $40 \%$ accounting for 580 of them agreed, $2 \%$ representing 29 of them were neutral, $3 \%$ accounting for 44 of them disagreed and strongly disagreed respectively on the questionnaire item 5 . By this, it could be deduced that large proportion of the respondents accepted that town unions have been involved in enlightening the community members on the place of education in the liberation of the people from ignorance and servitude.

\section{Test of Hypotheses}

\subsection{Hypothesis One}

The hypothesis tested here is stated as follows:

$\mathbf{H}_{\mathrm{A} 1}$ : Democratic governance has increased the contributions of town unions in the provision of basic education in rural communities in Ebonyi State.

Data collected on variables were subjected to chi-square test of independence at an alpha level of 0.05 . Summary of the test is presented in Table 1.

\subsection{Decision Rule}

Reject the null hypothesis $\left(\mathrm{H}_{0}\right)$ and accept the alternate hypothesis $\left(\mathrm{H}_{\mathrm{a}}\right)$, if the $\mathrm{P}$-Value is less than 0.05 .

Table 1: Chi-Square Test of Independence on Increased Contribution of Town Unions in the Provision of Basic Education in Rural Communities in Ebonyi State

\begin{tabular}{ccccccc}
\hline S/N & SA & $\mathrm{A}$ & $\mathrm{N}$ & $\mathrm{D}$ & $\mathrm{SD}$ & Total \\
\hline 1 & 493 & 697 & 109 & 94 & 58 & 1451 \\
& 638.2 & 544 & 68.4 & 138 & 62.4 & \\
2 & 653 & 573 & 58 & 116 & 51 & 1451 \\
& 638.2 & 544 & 68.4 & 138 & 62.4 & \\
3 & 986 & 348 & 44 & 44 & 29 & 1451 \\
& 638.2 & 544 & 68.4 & 138 & 62.4 & \\
4 & 305 & 522 & 102 & 392 & 130 & 1451 \\
& 638.2 & 544 & 68.4 & 138 & 62.4 & \\
5 & 754 & 580 & 29 & 44 & 44 & 1451 \\
& 638.2 & 544 & 68.4 & 138 & 62.4 & \\
Total & 3191 & 2720 & 342 & 690 & 312 & 7,255 \\
\hline
\end{tabular}

Source: SPSS Analysed Field Survey Data, 2016

Chi-Sq $=33.04+43.03+24.10+14.03+0.31+0.34+1.55+1.58+3.51+2.08+189.54+70.62$ $+8.70+64.03+17.88+173.96+0.89+16.51+467.51+73.23+21.01+2.38+22.70+64.03+$ $5.43=1321.99$

$$
\begin{aligned}
& X^{2}-\text { cal }=1321.99 \\
& D F=16, P-\text { Value }=0.05 \\
& X^{2} \text {-tab }=1.0433
\end{aligned}
$$

Decision: Reject null hypothesis and accept alternative hypothesis

The result of the analysis as presented in Table 1 shows that the Chi-Square calculated value is 1321.99 while the critical value at $95 \%$ confidence level is 1.0433 . The decision rule is to reject the null hypothesis when the chi-calculated value is greater than the critical value. Based on the decision rule, the null hypothesis was rejected and the alternative hypothesis has been accepted that the democratic governance has significantly increased the contributions of town unions in the provision of basic education in rural communities in Ebonyi State. 


\section{Discussions and Analysis}

This study has given an account of the contributions of the town unions to the provision of basic education in rural communities in Ebonyi State. Analysis of data revealed that the emergence of democratic governance in Nigeria since 1999 and its sustenance till 2015 has facilitated increased provision of basic education by town unions across rural communities in the State. These successes have been recorded because of the nature of democratic regime which has provided the rural people with conducive environment and climate that enhances the freedom of right choices, collective action and freedom from servitude.

It is imperative to mention that democratic governance has provided the fillips required to arouse increased collaboration between the town unions and community members in the provision of development projects such basic education in some rural communities in Ebonyi State. In specific terms democratic governance enabled the town unions to seek the views the community members in the choice of primary and secondary schools classroom projects constructed in the twelve communities that were surveyed during the study. Again, democratic governance promoted increased consultations between the town unions and community members in the mobilization of funds for the provision of instructional materials in the primary and secondary schools in rural communities in Ebonyi State. It was also revealed that democratic governance facilitated the involvement of community members by town unions in the advocacy for increased primary and secondary schools.

More than that, it aided increased collaboration between town unions and community members in the provision of recreational facilities and sponsorship of sporting events in primary and secondary schools in the rural communities. Besides, the prevailing democratic environment enabled the town unions to enlighten the community members on the place of education in the liberation of people from ignorance and servitude. The development promoted down-bottom approach and made the community members to see the projects as their own, hence their increased interests in partnering the town unions in the execution of basic educational projects in their various communities.

The issues raised in the discussion above, have received strong statistical supports in the analysis of questionnaire data and the chi square test of hypothesis. Furthermore, the analysis and the interpretation of FGD data from the interaction held with past and present executives of town unions and other stakeholders in the surveyed rural communities equally gave support to these assertions. For instance, the analysis of the FGD data in Ekka community in Ezza North Local Government Area shows that the town union has established three new primary schools, constructed two classroom blocks, equipped a science laboratory and built an exam hall at integrated secondary schools in the community. It also revealed that the town union in Ekka community provided tables, chairs and desks for uses in their primary and secondary schools. They also provided stipends to indigent students.

This analysis was corroborated by the observations we made during the field survey. The observations revealed that there has been apparent increase in contributions of town unions in the provision of educational projects under the democratic dispensation. However, it was observed that one of the buildings in the secondary school constructed during military is already in bad state as the roof is gradually collapsing and there is no indication that it has been any attention by town union. The respondents gave lack of funds due to high prevalence of poverty in the rural area as responsible for the gradual collapsing building not to have received the attention from the town union.

In Umuezeokoha community the town reconstructed a five classroom blocks with modern roofing sheets, repaired the roofs of six classrooms Community Primary School Oshiegbe blown off by wind at same school. The town union also constructed examination hall at Community Secondary Schools Oshiegbe and organized sensitization programmes to educate parents on the needs to release their children/wards to attend schools and to buy textbooks for them. Besides the town union undertook other projects such as the construction and renovation of 6 primary school blocks and construction of football pitches in their primary schools to boost sporting activities. The town union also donated trophies to primary and secondary schools to promote sport activities in 
the community. The town union has institutionalized reward for excellent academic performance and engaged P.T.A. teachers which they some stipends for the up keeps and equally pays tuition fee for indigent students demonstration outstanding performance in examinations.

The findings are in tandem with Ugwu (2013) which investigated town unions' contributions to educational development in Nsukka L.G.A. in Enugu state of Nigeria. The result of the study showed that town unions established and refurbished 40 primary schools within the period covered by the study, while at the same time, 19 secondary schools were constructed across the communities. The study equally revealed that Town Unions in Nsukka Local Government Area contributed in construction and renovating, existing structures in primary and post-primary institutions. They also helped in equipping the schools by providing some facilities like chair and tables for both teachers and pupils.

In Amagu community in Ikwo Local Government of Ebonyi State the town unions built primary schools in the 24 villages that make up the community and built three secondary schools, viz; Community Secondary Abina Amagu, Unity Secondary Item Amagu, Premier Secondary School Ndiagu Amagu. The town union also constructed two primary school buildings made up of ten classroom blocks with examination halls and four offices at the cost of $3.5 \mathrm{~m}$ at and constructed toilet facilities at schools primary school Ndiofoke Amagu. Town union has sponsored 27 university students, 18 polytechnic students and 25 students in colleges of education.

These findings agree with Waldman (2012) who after a critical study of democratic governance and its effects on the educational development policy in Unites States of America concluded that democratic governance promotes sustainable educational development opportunities by resolving educational inequalities especially in rural communities in developing countries. The findings of this were corroborated by Oladepo (1996) who examined how town unions contribute to the provision of basic education in rural areas in Oyo State, Nigeria. After the analysis of data, the researcher reported that out of the 55 primary schools in Kajola Local Government Area of Oyo State, only 7 are Local Government-owned while the larger proportion (48) schools were established by the Town unions. It must however be noted that most of the primary schools are located in the rural settlements of the LGA. This has added impetus to the theoretical argument that there is strong correlation between democracy and contributions of town unions to educational development.

\section{Conclusion and Recommendations}

The inception of democratic governance in 1999 and its sustenance till 2015 in Nigeria has stimulated increased contributions of town unions to the provision of basic education in rural communities iunions to rural development in Ebonyi State. It has further facilitated increased collaboration between the town unions and members of the communities in the initiation, planning, funding, execution and maintaining of basic education in the rural communities. The people oriented nature of democratic governance has brought the town unions executive closer than ever to the people and as such increased the synergy between the people and members of the town unions in many rural communities in execution of developmental projects. Following this positive development, the number of projects and programmes executed in under the democratic dispensation has increased remarkably.

This is evident in the areas of health, education and infrastructural development especially in the construction and maintenance of roads, bridges and culverts. The people in the rural communities are now seen as partners in progress in the provision of rural development projects in many rural communities of Ebonyi State. Despite these modest efforts made by the town unions in rural development in Ebonyi State, they are still constrained by some factors such as lack of funds due to high prevalence of poverty in many rural communities, illiteracy and undue interference from political office holders in the affairs of town unions. Worse still, lack of regular trainings and retraining of the town executives have put limitations on the town unions' capacities to function effectively in line with global best practices. The study recommends that government should provide periodic subvention to town unions to enable them have adequate fund for the provision of basic education projects in rural communities to meet the yearnings and aspirations of rural dwellers. 
Besides empowerment and poverty reduction programmes should be channeled through town unions to ensure that programme reaches the target audience. Again, there should be regular seminar, workshops and symposia to increase the skills and knowledge required for effective and efficient smooth operations of town unions.

\section{References}

Adebayo, A.M. (1995). The Role of Community-Based Organizations in Rural Settlement: Olorunda in Lagelu Local Government as a Case Study. Unpublished Professional Diploma Dissertation, Department of Town Planning, The Polytechnic, Ibadan.

Ake, C. (1996). Democracy and Development in Africa. Spectrum, Ibadan.

Ake, C. (1998). Is Africa Democratizing? Text of Guardian Annual Lecture in the Guidance DCC, 27.

Anderson, E. and McFarlane, J. (2004). Community as Partner. Lippincott: Williams and Wilkins Philadelphia.

Bashir, A.D. (2015). Evaluation of the contribution of Community Based Organisation (CBOs) to the development of communities in Nigeria (A Study of Offa Local Government Area, Kwara State). Unpublished M.Sc thesis submitted to the School of Postgraduate Studies, Ahmadu Bello University, Zaria.

Bollen, K. and Jackman, R. (1985). Economic and Noneconomic Determinants of Political Democracy in the 1960s. Research in Political Sociology, 1: 27-48.

Bollen, K.A. (1979). Political democracy and the timing of development. American Sociological Review, 44: 205218.

Bonsu, S. (1983). Rural Development and Bureaucracy in Nigeria. Ibadan: Longman.

Boreham, N. (2004). A theory of collective competence: challenging the neoliberal individualization of performance at work. British Journal of Educational Studies, 52(1): 5-17.

Cheema, G.S. and Maguire, L. (n.d). Democracy, Governance and Development: A Conceptual Framework. Available online at http://unpan1.un.org/intradoc/groups/public/documents/un/unpan005781.pdf $(04 / 01 / 2014$

Coulter, P.B. (1975). Social mobilization and liberal democracy: A macro-quantitative analysis of global and regional models. Lexington: Lexington Press.

Cutright, P. (1987). National political development: measure and analysis. American Sociological Review, 28: 17-63.

Dahl, R. (1989). Democracy and its Critics. New Haven, CT: Yale University Press.

Deway, J. (1927). The Publics and Its Problems. Denver: Allan Swallow.

Diamond, L. (1996). Civil Military Relations and Democracy. London: Oxford University Press.

Doyle, M. W. (1983). Kant, Liberal Legacies and Foreign Affairs. Philosophy and Public Affairs, 12 (3): 205-235.

Eme, I.E., Eluma, I.J. and Ukah, F.O. (2012). Rural Community Perspectives. Interdisciplinary Journal of Contemporary Research Business, 4(5): 46-52.

Feng, Y. (2003). Democracy, Governance, and Economic Performance: Theory and Evidence. Cambridge, MA: The MIT Press.

Flanigan, W.H. and Fogelman, E. (19971). Patterns of political analysis. In J.V. Gillespie and B.A. Nesvold (eds), Macro-Quantitative analysis: conflict, development and democratization. London: Beverly Hills, Sage.

Flora, P. (1973). Historical processes of social mobilization: Urbanization and literacy, 1850-1965. In S.N. Eisenstadt and S. Rokkan (eds), Building statea and nations: Models and data resources. Beverly Hills: Sage.

Fukuyama, F. (1992). The End of History and the Last Man. New York: Free Press.

Huntington, S. P. (1993). The Clash of Civilization? Foreign Affairs, 72 (3): 22-49.

Kaplan, R. (1997). Was Democracy Just a Movie? The Atlantic Monthly.

Kiyaga-Nsubuga, J. (2015). National consultations on the post 2015 international development framework 'The future we want'. Final Report. Available online at http://www.unug.org/sites/default/files/reports/National\%20Post\%202015\%20Consultations_1st\%20round.pdf

Kulig, J. (2000). Community resiliency: The potential for community health nursing theory development. Public Health Nursing, 17(5): 374-385.

Lavery, S. (2005). The Community action model: A Community-driven model designed to address disparities in health. American Journal of Public Health, 5(4): 611-616.

Lerner, D. (1958). The Passing of Traditional Society: Modernizing the Middle East. Second Printing. Glencoe, III.: Free Press.

Lipset, S.M. (1959). Some Social Requisites of Democracy: Economic Development and Political Legitimacy. American Political Science Review, 53: 69-105.

Maiangwa, J.S. (2013). Between Western Liberal Democracy and Political Contest in Africa. In C.J. Nwanegbo, 
O. Omadachi and J. Tsuwa (eds), Discourses in Governance, Democracy and Development in Contemporary Nigeria. Abuja, Lagos, Makurdi: SAP Publishing House.

Marquette, J. (1974). Social change and political mobilization in the United States: 1870-1960. The American Political Science Review, 66: 475-493.

Menocal, A.R. (2007). Analyzing the Relationship between Democracy and Development: Defining Basic Concepts and Assessing Key Linkages. Background Note (1) Prepared for the Wilton Park Conference on Democracy and Development, $23^{\text {rd }}-25^{\text {th }}$ October.

Needler, M.C. (1968). Political development and socio-economic development: The case of Latin America. The American Political Science Review, 62: 23-41.

Neubauer, D.E. (1967). Some conditions of democracy. The American Political Science Review, 61: 594-612.

Nnoli, O. (2011). The struggle for democracy in Nigeria. Enugu: Pan African Center for Research on Peace and Conflict Resolution (PACREP).

Nwankwo, B.C. (2014). Town Unions Grow Communities. Available online at http://www.thenationline.ng.net/new/up.content/uploads2012/08/logo2.png. Accessed on 25/04/2016.

Nwobi, G. (2007). Rural Development: Theories and strategies. Enugu: Nino Rev: Charles and Patrick Ltd.

Nwosu, A.C. (1999). Episodes in Encounter Between the Town Unions and Eze Institutions. Available online at http;//www.assatashakur.org/forum/nanascircle/34548. Accessed on 25/04/2016.

OECD (2001). Citizens as partners in policy making. OECD Focus Public Management Newsletter, $21:$ 1-8.

Okolie, A.M. (2015). Global Political Economy and the Development of Underdevelopment: Different People, Same Market and Clarification of Poverty. An Inaugural Lecture of the University of Nigeria, Nsukka delivered on $14^{\text {th }}$ May.

Oladepo, O. T. (1996). The Role of Community-Based Organizations in the Regional Development of Oke-Ogun Area, of Oyo State. Unpublished Professional Diploma Dissertation, Department of Town Planning, The Polytechnic, Ibadan.

Omenka, Z.I. and Akaan, R. (2013). Leadership, Democracy and Implications for National Development in Nigeria. In C.A. Nwamegbo, O. Omudachi and J.T. Tsuwg (eds), Discourses in Governance, Democracy and Development in Cotemporary Nigeria. Abuja, Lagos, Makurdi: SAP Publishing House.

Onyeozu, A.M. (2010). Analysis of the influence of community based organizations on community development in Rivers State, Nigeria. Academia Arena, 2(10): 49-53.

Parry, T. R. (1997). Achieving Balance in Decentralization: A Case Study of Education Decentralization in Chile. World Development, 25(2): 211-225.

Pippa, N. (1999). Critical Citizens: Global Support for Democratic Governance. Oxford: Oxford University Press.

Przeworski, A. (2000). Democracy and Development: Political Institutions and Well-being in the World 19501990. Cambridge: Cambridge University Press

Przeworski, A. and Limongi, F. (1993). Political Regimes and Economic Growth. Journal of Economic Perspectives, 7 summer.

Racher, F. (2007). Running Head: The Community Health Action Model: Health Promotion by the Community. Brandon University Press, Lancaster.

Santiso, C. (1997). Democratic Governance: Economic and Political Development in New Democracies. Background paper for the International Institute of Democracy and Electoral Assistance (IIDEA).

Sen, A. (1998). Democracy as a Universal Value. Journal of Democracy, 10(3): 3-17.

Sen, A. (1999b). Development as Freedom. New York: Anchor Books.

Sisk, T.D. (2011). Democracy at the Local Level, the International Handbook on Participation, Representation: Conflict Managerial and Governance. Sweden Bulls Trictax.

Tendler, J. and Rodrigo, S. (1999). The Rise of Social Funds: What Are They a Model Of? For the MIT/UNDP Decentralization Project Management Development and Governance Division, United Nations Development Porgramme, New York.

Ugwu, L.C. (2013). Town Unions and Community Development in Nigeria: A Study of Nsukka LGA in Enugu State (1995-2010). An MSc Dissertation, Submitted to the Department of Political Science, University of Nigeria, Nsukka.

United Nations (2000). Community Development and National Development. Report of an Ad Hoc Group of Experts, New York: UN.

Waldman, D.K. (2012). Democratic Governance: Understanding Democratic Governance and its Effect on the Educational Development Policy. Available online at https://www.academia.edu/1352653/Democratic _Governance_Understanding_Democratic_Governance_and_its_Effect_on_the_Educational_Developme ntal_Policy. on 07/28/2016.

Westergaärd, K. and Alam, M. M. (1995). "Local government in Bangladesh: Past Experiences and Yet Another Try." World Development, 23 (4): 670-690. 